\title{
Doping of $\mathrm{Bi}-\mathrm{Sr}-\mathrm{Ca}-\mathrm{Cu}-\mathrm{O}$ superconductors with $\mathrm{Pb}, \mathrm{Sn}$ and $\mathrm{Ag}$
}

\author{
F HANIC, G PLESCH, M JERGEL ${ }^{\dagger}$, V ŠTRBIK ${ }^{\dagger}$, V ŠMATKO \\ and R ADAM ${ }^{\dagger}$ \\ Institute of Inorganic Chernistry, Slovak Academy of Sciences, 84236 Bratislava. \\ Czechoslovakia \\ ${ }^{\dagger}$ Electrotechnical Institute, Slovak Academy of Sciences, 84239 Bratislava, Czechoslovakia
}

\begin{abstract}
Basic and substituted superconductors in the homologous series $\mathrm{Bi}_{2} \mathrm{Sr}_{2} \mathrm{Ca}_{n-1} \mathrm{Cu}_{n}$ $\mathrm{O}_{2 n+4+y} \mathrm{Bi}_{2-x / 2} \mathrm{Sr}_{2-x i 2} \mathrm{~L}_{x} \mathrm{Ca}_{n-1} \mathrm{Cu}_{n} \mathrm{O}_{2 n+4+y}$ and $\mathrm{Bi}_{2} \mathrm{Sr}_{2-x} \mathrm{~L}_{x} \mathrm{Ca}_{n-1} \mathrm{Cu}_{n} \mathrm{O}_{2 n+4+y}(\mathrm{~L}=\mathrm{Sn} . \mathrm{Pb}$ or $\mathrm{Ag}, x=0-0.4, n=2,3$ or 4 ) have been synthesized. All the prepared ceramic samples show superconducting behaviour with zero resistance at $T_{c}=70$ to $85 \mathrm{~K}$. The compounds with $n=3$ or 4 showed onset temperature around $115 \mathrm{~K}$ indicating involvement of a disproportionate solid-state reaction and formation of a two-phase system. The phase involving tin or lead oxides showed similar superconducting properties. Final rapid quenching of samples contributed to preservation of the high temperature equilibria with higher solubility of tin oxide in the quaternary system $\mathrm{Bi}-\mathrm{Sr}-\mathrm{Ca}-\mathrm{Cu}-\mathrm{O}$. Silver was not soluble but precipitated in a colloidal form at interfaces between the crystalline grains.
\end{abstract}

Keywords. Superconductors: $\mathrm{Bi}-\mathrm{Sr}-\mathrm{Ca}-\mathrm{Cu}-\mathrm{O}$; doping.

\section{Introduction}

A typical structural feature of the high- $T_{c}$ superconductors of the type $\mathrm{Bi}_{2} \mathrm{Sr}_{2} \mathrm{Ca}_{n-1} \mathrm{Cu}_{n} \mathrm{O}_{2 n+4+y}, \mathrm{Bi}_{2-x / 2} \mathrm{Sr}_{2-x / 2} \mathrm{~L}_{x} \mathrm{Ca}_{n-1} \mathrm{Cu}_{n} \mathrm{O}_{2 n+4+y}$ as well as $\mathrm{Bi}_{2} \mathrm{Sr}_{2-x} \mathrm{~L}_{x}$ $\mathrm{Ca}_{n-1} \mathrm{Cu}_{n} \mathrm{O}_{2 n+4+y}(\mathrm{~L}=\mathrm{Sn}$ or $\mathrm{Pb}, x=0-0.4, n=2,3$ or 4$)$ is the layered arrangement, in which the lamella $\mathrm{BiO}-\mathrm{SrO}-\mathrm{CuO}_{z}-\left(\mathrm{Ca}-\mathrm{CuO}_{z}\right)_{n-1}-\mathrm{SrO}-\mathrm{BiO}$ represents, in the first approximation, a stacking unit. In the sandwich arrangement, the double layers $\mathrm{BiO}-\mathrm{BiO}$ close in $n$-parallel superconducting layers $-\mathrm{CuO}_{z^{-}}$. The $-\mathrm{SrO}-\mathrm{CuO}_{z^{-}}$ $\left(\mathrm{Ca}-\mathrm{CuO}_{z}\right)_{n-1}-\mathrm{SrO}-$ slabs form a close packed perovskite-like sequence (Maeda et al 1988; Tarascon et al 1988; Gao et al 1988; Subramanian et al 1988). The bond strength between the two adjacent $(\mathrm{BiO})_{2}$ layers is rather weak. The coordination of the $\mathrm{Bi}$ ion in the $(\mathrm{BiO})_{2}$ double rocksalt type layer is 6 . The actual structures in the homologous series $\mathrm{Bi}_{2} \mathrm{Sr}_{2} \mathrm{Ca}_{n-1} \mathrm{Cu}_{n} \mathrm{O}_{2 n+4+y}$ are incommensurate long-period modulated superstructures presumably induced by the extra oxygen atom in the $\mathrm{BiO}$ layers and by the misfit between the $(\mathrm{BiO})_{2}$ rocksalt-like layers and the perovskite-like slabs. Modulation was found to consist of an almost sinusoidal displacement of the $\mathrm{Bi}$ and $\mathrm{Sr}$ atoms in the $a$ and $c$ directions of the unit cell and a similar displacement of the $\mathrm{Cu}$ atoms in the $c$ direction only (Zandbergen et al 1988).

The superconducting transition temperature $T_{c}$ increases with increasing number of $-\mathrm{CuO}_{z^{-}}$layers in the sandwich stacking unit of the $\mathrm{Bi}_{2} \mathrm{Sr}_{2} \mathrm{Ca}_{n-1} \mathrm{Cu}_{n} \mathrm{O}_{2 n+4+y}$ homologue, i.e. with increasing $n$ value. Partial substitution performed with lead oxide in the $\mathrm{Bi}_{2} \mathrm{Sr}_{2} \mathrm{Ca}_{n-1} \mathrm{Cu}_{n} \mathrm{O}_{2 n+4+y}$ homologue was found to support formation of the high- $T_{c}$ phase (Takano et al 1988).

Since $\mathrm{Sn}$ ions show similar double valence fluctuation of the type $\mathrm{M}^{n+}+$ $2 \mathrm{O}^{2-} \leftrightarrow \mathrm{M}^{(n-2)+}+\mathrm{O}_{2}^{2-}$, such as typical lead valence states, $\mathrm{Pb}^{0}, \mathrm{~Pb}^{2+}$ and $\mathrm{Pb}^{4+}$ show (the stable valence states differ by two electrons), we tried to prove the partial substitution of the type $\mathrm{Bi}_{2} \mathrm{Sr}_{2-x} \mathrm{Sn}_{x} \mathrm{Ca}_{n-1} \mathrm{Cu}_{n} \mathrm{O}_{2 n+4+y}$ and $\mathrm{Bi}_{2-x} \mathrm{Sr}_{2-x} \mathrm{Sn}_{2 x} \mathrm{Ca}_{n-1}$ 
$\mathrm{Cu}_{n} \mathrm{O}_{2 n+4+y}$ and its influence on the superconductive properties of the solid solutions. This work also aims at a comparison of the superconducting properties of the corresponding lead and tin solid solutions. We also tried to prove the role of the $\mathrm{Ag}$ ions in the system $\mathrm{Bi}-\mathrm{Sr}-\mathrm{Sn}(\mathrm{Pb})-\mathrm{Ca}-\mathrm{Cu}-\mathrm{O}$.

\section{Experimental}

The samples of nominal compositions of $\mathrm{Bi}_{2} \mathrm{Sr}_{2} \mathrm{Ca}_{n-1} \mathrm{Cu}_{n} \mathrm{O}_{2 n+4+y}, \mathrm{Bi}_{2} \mathrm{Sr}_{2-x} \mathrm{~L}_{x} \mathrm{Ca}_{n-1}$ $\mathrm{Cu}_{n} \mathrm{O}_{2 n+4+y}$ and $\mathrm{Bi}_{2-x / 2} \mathrm{Sr}_{2-x / 2} \mathrm{~L}_{x} \mathrm{Ca}_{n-1} \mathrm{Cu}_{n} \mathrm{O}_{2 n+4+y}$ where $\mathrm{L}=\mathrm{Sn}$ or $\mathrm{Pb}, n=2,3$ or 4, $x=0.4$, were prepared by solid-state reaction of the equivalent amounts of corresponding oxides $\left(\mathrm{Bi}_{2} \mathrm{O}_{3}, \mathrm{CuO}, \mathrm{PbO}_{2}, \mathrm{SnO}_{2}\right)$ and carbonates $\left(\mathrm{CaCO}_{3}, \mathrm{SrCO}_{3}\right)$. First, the homogenized mixture of oxides (without $\mathrm{SnO}_{2}$ or $\mathrm{PbO}_{2}$ ) and carbonates was decarbonated at $830-840^{\circ} \mathrm{C}$ for $4 \mathrm{~h}$. The product was then homogenized with equivalent amounts of $\mathrm{SnO}_{2}$ or $\mathrm{PbO}_{2}$, compressed into pellets, sintered for $1 \mathrm{~h}$ at $880^{\circ} \mathrm{C}$ and finally annealed at $850^{\circ} \mathrm{C}$ for $4 \mathrm{~h}$ in air by quenching or slow cooling $\left(100^{\circ} \mathrm{C} / 1 \mathrm{~h}\right)$. In some experiments, in which the influence of annealing temperature on the structure, phase composition and superconducting properties of the homologues was tested, sintering temperatures of 917,894 and $880^{\circ} \mathrm{C}$ were used for $20 \mathrm{~min}$, followed by quenching of samples.

All prepared samples were characterized by measuring the $R(T)$ dependence, for which the d.c. four-point resistance method was used. X-ray diffraction patterns were taken on a Philips powder diffractometer using $\mathrm{CuK}_{\alpha}$ radiation.

\section{Results, discussion and conclusions}

The resistance $R(T)$ measurements showed that all prepared homologue compounds $\mathrm{Bi}_{2} \mathrm{Sr}_{2} \mathrm{Ca}_{n-1} \mathrm{Cu}_{n} \mathrm{O}_{2 n+4+y}, \mathrm{Bi}_{2} \mathrm{Sr}_{1.6} \mathrm{~L}_{0.4} \mathrm{Ca}_{n-1} \mathrm{Cu}_{n} \mathrm{O}_{2 n+4+y}$ and $\mathrm{Bi}_{1.8} \mathrm{Sr}_{1.8} \mathrm{~L}_{0.4} \mathrm{Ca}_{n-1}$ $\mathrm{Cu}_{n} \mathrm{O}_{2 n+4+y}(\mathrm{~L}=\mathrm{Sn}$ or $\mathrm{Pb}, n=2,3$ or 4$)$ were superconducting with zero resistance at $T_{c}=70$ to $85 \mathrm{~K}$. However, the phases with $n=3$ or 4 showed the onset temperature around $115 \mathrm{~K}$ indicating involvement of a disproportionate solid-state reaction with formation of a two-phase system. A typical $R(T)$ record is shown in figure 1 for the $\mathrm{Bi}_{2} \mathrm{Sr}_{2} \mathrm{Ca}_{2} \mathrm{Cu}_{3} \mathrm{O}_{10+y}$ homologue sintered at $880^{\circ} \mathrm{C}$ for $1 \mathrm{~h}$ and annealed at $850^{\circ} \mathrm{C}$ for $4 \mathrm{~h}$, followed by quenching of sample.

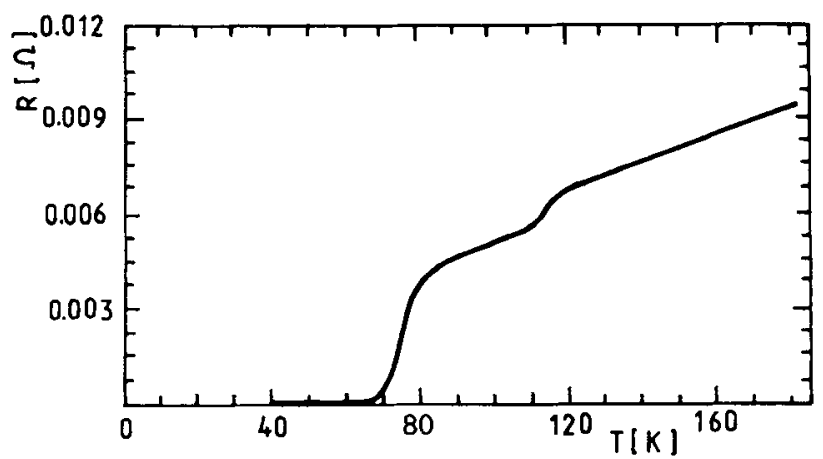

Figure 1. $R(T)$ dependence for $\mathrm{Bi}_{2} \mathrm{Sr}_{2} \mathrm{Ca}_{2} \mathrm{Cu}_{3} \mathrm{O}_{10+y}$ sintered at $880 \mathrm{C}$ for $\mathrm{th}$ and annealed at $850 \mathrm{C}$ for $4 \mathrm{~h}$ in air, followed by quenching of sample. 


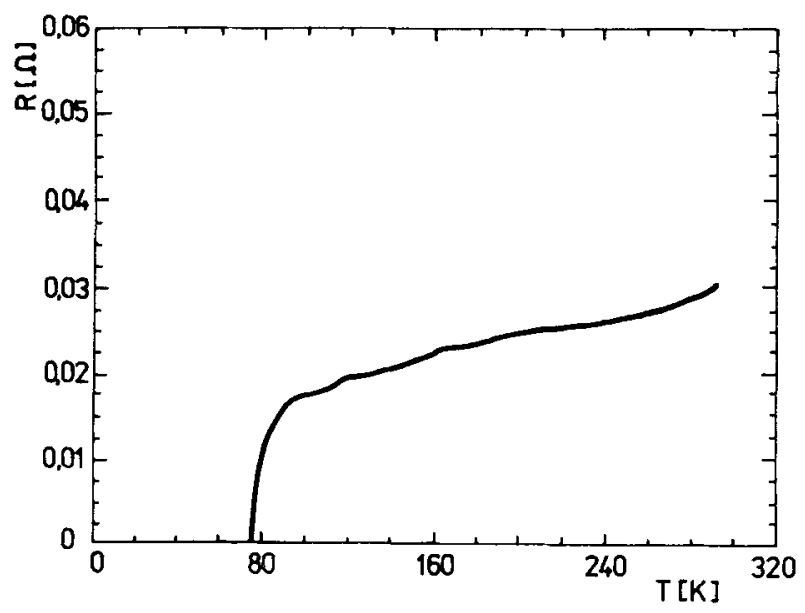

Figure 2. $R(T)$ dependence for $\mathrm{Bi}_{1.8} \mathrm{Sr}_{1.8} \mathrm{~Pb}_{0.4} \mathrm{Ca}_{2} \mathrm{Cu}_{3} \mathrm{O}_{10+y}$ sintered at $880^{\circ} \mathrm{C}$ for $1 \mathrm{~h}$ and annealed at $850 \mathrm{C}$ for $4 \mathrm{~h}$ in air, followed by quenching of sample.

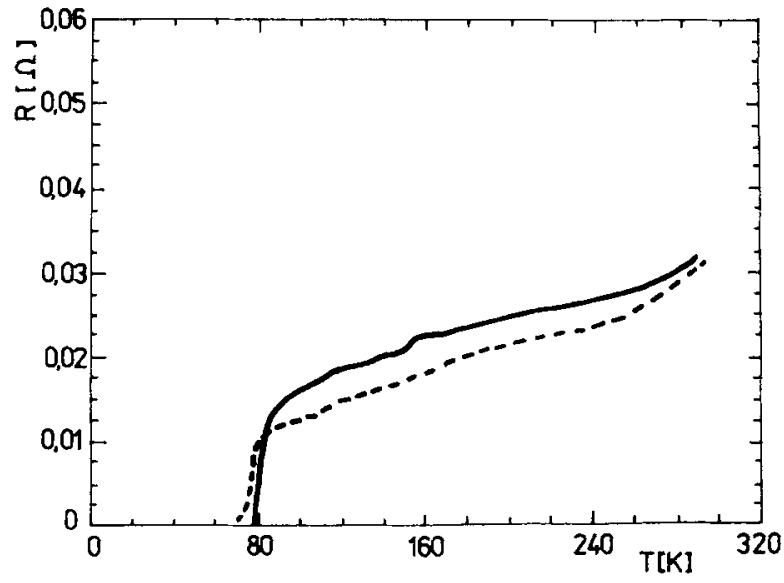

Figure 3. $R(T)$ dependence for $\mathrm{Bi}_{1.8} \mathrm{Sr}_{18} \mathrm{Sn}_{0.4} \mathrm{Ca}_{2} \mathrm{Cu}_{3} \mathrm{O}_{10+y}$ sintered at $870^{\circ} \mathrm{C}$ for $1 \mathrm{~h}$ and annealed at $850 \mathrm{C}$ for $4 \mathrm{~h}$ in air, followed by quenching (full line) or by slow cooling (dotted line).

The $R(T)$ behaviour of the $\mathrm{Sn}$ and $\mathrm{Pb}$ homologues $\mathrm{Bi}_{1.8} \mathrm{Sr}_{1.8} \mathrm{~L}_{0.4} \mathrm{Ca}_{2} \mathrm{Cu}_{3} \mathrm{O}_{10+y}$ is compared in figures 2 and 3 . The $\mathrm{Pb}$ homologue in figure 2 was sintered at $880^{\circ} \mathrm{C}$, the $\mathrm{Sn}$ homologue in figure 3 at $870^{\circ} \mathrm{C}$ for $1 \mathrm{~h}$ followed by annealing at $850^{\circ} \mathrm{C}$ for $4 \mathrm{~h}$ in both cases. The $\mathrm{Pb}$ sample was quenched after annealing, while the $\mathrm{Sn}$ sample was either quenched (full line in figure 3 ) or slowly cooled (dotted line in figure 3). The $R(T)$ characteristics of quenched $\mathrm{Pb}$ and $\mathrm{Sn}$ samples are approximately similar to the lower zero resistance temperature value of the $\mathrm{Pb}$ homologue $\left(T_{c}=75 \mathrm{~K}\right)$ in comparison with the $\mathrm{Sn}$ homologue $\left(T_{\mathrm{c}}=80 \mathrm{~K}\right)$. However, the slow cooling of the Sn sample changed its $R(T)$ characteristics unfavourably, the $T_{c}$ being $71 \mathrm{~K}$. This is due to precipitation of a non-superconducting $\mathrm{SnO}$ phase, as demonstrated by the $\mathrm{X}$-ray powder diffraction record in figure 4 (the upper part of the picture). 


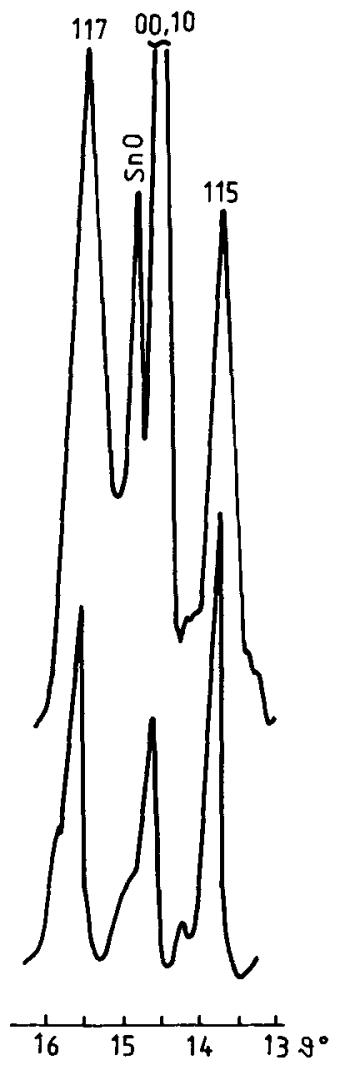

Figure 4. Part of the $\mathrm{X}$-ray powder diffraction records of the $\mathrm{Bi}_{1.8} \mathrm{Sr}_{1.8} \mathrm{Sn}_{6.4} \mathrm{Ca}_{2} \mathrm{Cu}_{3} \mathrm{O}_{10+y}$ samples characterized in figure 3: upper part, quenched sample; lower part, slowly cooled sample.

The influence of the sintering temperature on the $R(T)$ characteristics is shown in figure 5. Annealing at 917,894 and $880^{\circ} \mathrm{C}$ (lines 1,2 and 3) of the homologue $\mathrm{Bi}_{1.8} \mathrm{Sr}_{1.8} \mathrm{~Pb}_{0.4} \mathrm{CaCu}_{2} \mathrm{O}_{8+y}$ for $20 \mathrm{~min}$ gave the best results for the lowest temperature with the onset temperature of $85 \mathrm{~K}$ with $T_{\mathfrak{c}}=50 \mathrm{~K}$, while sintering at $917 \mathrm{~K}$ resulted in the onset temperature of $80 \mathrm{~K}$ with $T_{c}=30 \mathrm{~K}$.

The importance of sintering at higher temperatures is demonstrated for instance on the $\mathrm{Bi}_{1.8} \mathrm{Sr}_{1,8} \mathrm{~Pb}_{0.4} \mathrm{Ca}_{2} \mathrm{Cu}_{3} \mathrm{O}_{10+y}$ phase. When the homologue was sintered at $850^{\circ} \mathrm{C}$ for $10 \mathrm{~h}$, it showed a semiconducting character (figure 6, line 2) and an onset temperature value of $90 \mathrm{~K}$, with the zero resistance temperature value $T_{c}=76 \mathrm{~K}$. The sintering of the sample at $880^{\circ} \mathrm{C}$ followed by annealing at $850^{\circ} \mathrm{C}$ for $4 \mathrm{~h}$ changed the semiconducting character into metallic one (figure 6 , line 1) with the onset temperature of $80 \mathrm{~K}$ and $T_{c}=72 \mathrm{~K}$.

The additions of $\mathrm{Ag}_{2} \mathrm{O}(0.016,0.16,1.6$ and $10.0 \mathrm{at} . \% \mathrm{Ag})$ did not change unit cell parameters of the $\mathrm{Bi}_{2} \mathrm{Sr}_{2} \mathrm{Ca}_{2} \mathrm{Cu}_{3} \mathrm{O}_{10+y}$ phase thus confirming that the $\mathrm{Ag}$ component did not enter the structure. However, the presence of silver precipitated at interfaces between the crystalline grains of the superconductor, influenced significantly the texturing of the ceramic bulk. 


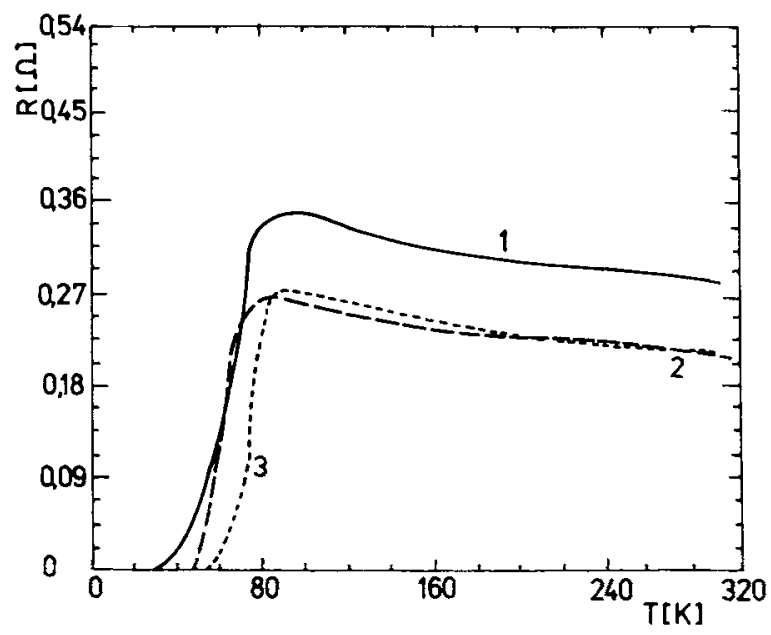

Figure 5. $R(T)$ dependence for samples $\mathrm{Bi}_{1.8} \mathrm{Sr}_{1.8} \mathrm{~Pb}_{0.4} \mathrm{CaCu}_{2} \mathrm{O}_{k+y}$ sintered at $917^{\circ} \mathrm{C}$ (line 1 ), $894 \mathrm{C}$ (line 2) and $880^{\circ} \mathrm{C}$ (line 3) for $20 \mathrm{~min}$ in air and then quenched.

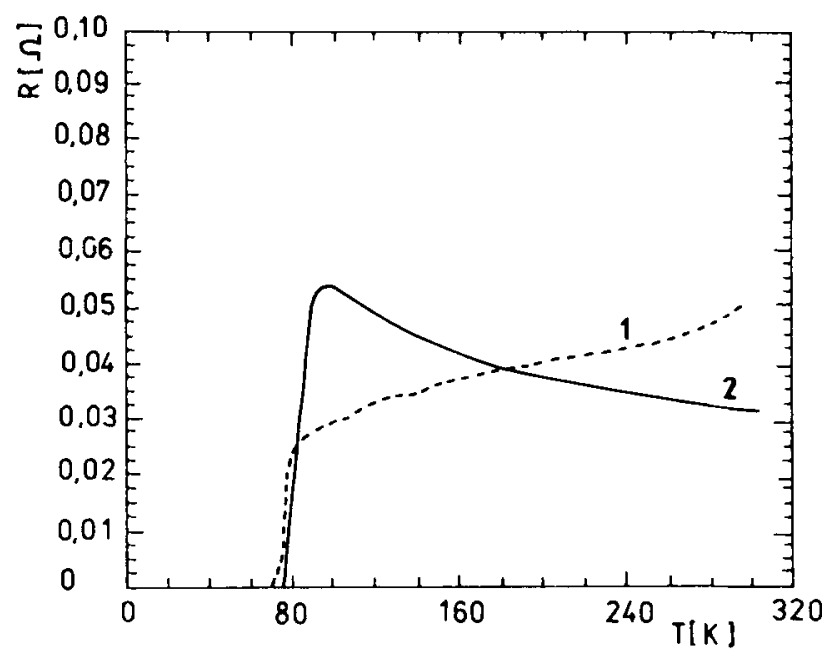

Figure 6. $R(T)$ dependence for $\mathrm{Bi}_{1} \mathrm{Sr}_{18} \mathrm{~Pb}_{0.4} \mathrm{Ca}_{2} \mathrm{Cu}_{3} \mathrm{O}_{10+y}$ sintered at $880^{\circ} \mathrm{C}$ for $1 \mathrm{~h}$ followed by annealing at $850^{\circ} \mathrm{C}$ for $4 \mathrm{~h}$ in air (line 1 ) or annealed only at $850^{\circ} \mathrm{C}$ for $10 \mathrm{~h}$ in air (line 2)

In conclusion. we may say the substitution of $\mathrm{Sn}$ for $\mathrm{Bi}$ and $\mathrm{Sr}$ in the homologous series $\mathrm{Bi}_{2-x} \mathrm{Sr}_{2-x} \mathrm{Sn}_{2 x} \mathrm{Ca}_{n-1} \mathrm{Cu}_{n} \mathrm{O}_{2 n+4+y}$ or $\mathrm{Bi}_{2} \mathrm{Sr}_{2-x} \mathrm{Sn}_{x} \mathrm{Ca}_{n-1} \mathrm{Cu}_{n} \mathrm{O}_{2 n+4+y}$ results in similar superconducting behaviour of the phases, as observed in $\mathrm{Pb}$ substitution. Substitution of $\mathrm{Sn}$ does not change the unit cell volume; however, relative changes of the $a, b, c$ parameters take place. 


\section{References}

Gao Y, Lee P, Coppens P, Subramanian M A and Sleight A W 1988 Science 241954

Maeda H, Tanaka Y, Fukutomi M and Asano T 1988 Jpn J. Appl. Phys. Lett. 27 L209

Subramanian M A, Torardi C C, Calabrese J C, Gopalakrishnan J, Morrissey K J, Askew T R, Flippen R B, Chowdhry U and Sleight A W 1988 Science 2391015

Takano M, Takada J, Oda K, Kitaguchi H, Miura Y, Ikeda Y, Tomii Y and Mazaki H $1988 \mathrm{Jpn} \mathrm{J.} \mathrm{Appl.}$ Phys. (Preprint)

Tarascon J M, Page Y, Barboux P, Bagley B G, Green L H, McKinnon W R, Hull G W, Giroud M and Hwang D M 1988 Phys. Rev. B37 9382

Zandbergen H W, Groen W A, Mijhoff F C, van Tendeloo G and Amelinckx S 1988 Physica C156 325 